OPEN ACCESS

Edited by:

Humberto Lanz-Mendoza, National Institute of Public Health (Mexico), Mexico

Reviewed by: Shihao Li, Chinese Academy of Sciences (CAS),

China

Annalisa Grimaldi,

University of Insubria, Italy

${ }^{*}$ Correspondence:

Cui-jie Kang

cjkang@sdu.edu.cn

${ }^{\dagger}$ These authors have contributed equally to this work and share first authorship

Specialty section:

This article was submitted to Comparative Immunology, a section of the journal

Frontiers in Immunology

Received: 02 November 2021 Accepted: 06 January 2022 Published: 31 January 2022

Citation:

Ding $D$, Sun $X-j$, Yan $M$, Chen Q, Gao L and Kang C-j (2022) The ECSIT Mediated

Toll3-Dorsal-ALFs Pathway Inhibits Bacterial Amplification in Kuruma Shrimp.

Front. Immunol. 13:807326. doi: 10.3389/fimmu.2022.807326

\section{The ECSIT Mediated Toll3-Dorsal- ALFs Pathway Inhibits Bacterial Amplification in Kuruma Shrimp}

\author{
Ding Ding ${ }^{\dagger}$, Xue-jun Sun ${ }^{\dagger}$, Meng Yan, Qi Chen, Lin Gao and Cui-jie Kang ${ }^{*}$ \\ Shandong Provincial Key Laboratory of Animal Cells and Developmental Biology, School of Life Sciences, Shandong \\ University, Qingdao, China
}

The Toll signaling pathway plays an important role in animal innate immunity. However, its activation and signal transmission greatly differ across species and need to be investigated. Shrimp farming is a worldwide economic activity affected by bacterial disease from the 1990s, which promoted research on shrimp immunity. In this study, we first proved that, among the three identified Toll receptors in Marsupenaeus japonicus kuruma shrimp, Toll 3 plays a pivotal role in initiating the antibacterial response in vivo, especially upon anti-Staphylococcus aureus infection. Further research showed that this result was due to the activation of the Dorsal transcription factor, which induced the expression of two anti-lipopolysaccharide factors (Alfs). Moreover, the evolutionarily conserved signaling intermediate in Toll pathways, ECSIT, was proved to be needed for signal transmission from Toll 3 to Dorsal and the expression of anti-lipopolysaccharide factors. Finally, the mortality assay showed that a Toll3-ECSIT-Dorsal-Alf axis was functional in the anti-S.aureus immunity of $M$. japonicus shrimp. The results provide new insights into the function and signal transduction of the Toll pathway in aquatic species and offer basic knowledge for shrimp disease control and genetic breeding.

Keywords: Toll, Ecsit, Dorsal, antimicrobial peptides (AMP), Staphylococcus aureus, Vibrio anguillarum, antilipopolysaccharide factor (Alf)

\section{INTRODUCTION}

Innate immunity is a basic first defense mechanism of multicellular organisms. It is generally initiated by recognizing pathogen-associated molecular patterns (PAMPs) of invading organisms via multiple membrane-located pattern recognition receptors (PRRs) on the host cell $(1,2)$. Among PRR members, the Toll (invertebrate) or Toll-like receptor (TLR) (vertebrate) superfamily is the most important and multifunctional PRR family member (3-5). To date, the activation and transduction of the Toll/TLR signaling pathway in mammals and fruit fly species have been well illustrated, namely, the activation of Toll/TLR by specific ligands, recruitment of downstream signaling molecules, activation of transcription factor translocation, and induction of effector molecule production $(6,7)$. Studies have shown that the basic function and components of Toll/TLR 
signaling are similar across various species, unlike the differing activation and transduction of immune signals downstream of them. For instance, the classical Toll pathway in Drosophila responds to external infection with Gram-positive bacteria and fungi and oral infection with several RNA viruses. The activation of Toll receptors needs a series of proteinase cascade reactions and cleavage of the Spätzle ligand. After the phosphorylation and degradation of the inhibitor Cactus (mammalian I $\mathrm{KB}$ homologue), the transcription factor Dorsal or the Dorsalrelated immunity factor (Dif) is released and translocated to the nucleus to induce the expression of antimicrobial peptides (AMPs) $(8,9)$. By contrast, several TLRs in humans could recognize a broad range of PAMPs directly. Then, additional signaling adaptor proteins, such as TAK/TAB and IKKs (which are absent from the Drosophila Toll signaling pathway but present in its imd signaling pathway) are recruited for signal transduction. Additionally, more than one transcription factor (namely, nuclear factor- $\mathrm{\kappa B}[\mathrm{NF}-\kappa \mathrm{B}]$, interferon-regulatory factors [IRFs], cyclic AMP-responsive element-binding protein [CREB], or activator protein 1 [AP1]) are activated downstream of different TLR receptors and trigger the production of proinflammatory cytokines or Type I IFNs (IFN $\alpha$ and IFN $\beta$ ). Besides that, while the function of all human TLRs is activating immune signal transduction, only five Drosophila Toll receptors (Toll, Toll2, Toll5, Toll7, and Toll9) among the nine identified, have been implicated in the fruit fly immune response thus far (10).

Research on the shrimp innate immune system has been drawing extensive interest since the 1990s, because of the economic value of the animal and the need for disease control strategies (11-15). To date, dozens of Toll receptors have been identified in various shrimp species, namely, three MjTolls in Marsupenaeus japonicas (16), nine LvTolls in Litopenaeus vannamei (17), one FcToll in Fenneropenaeus chinensis (18), two PmTolls in Penaeus monodon (19, 20), five MrTolls in Macrobrachium rosenbergi, and six PcTolls in Procambarus clarkii (21). Besides that, some key components involved in classic Toll pathway signal transduction were also identified in shrimp (namely, Dorsal, Cactus, Spätzle, MyD88, Tube, Pelle, TRAF6, etc.), highlighting the conservation of the Toll signaling pathway in aquatic arthropods (22-29). To date, the shrimp Tolls have been shown to respond to bacterial or viral infection and lead to Dorsal activation and the expression of AMPs in several shrimp species. However, only two identified Toll signaling pathways have been reported, the PcToll2-ATF4-ALF1/2 pathway in $P$. clarkii exposed to Vibrio parahemolyticus and the LvToll4-Dorsal- ALF1/ LYZ1 pathway in L. vannamei responding to white spot syndrome virus infection $(17,30)$. The key Toll receptor responses to different pathogens and the downstream signal transduction pathways regulating effector genes are still largely unknown in other shrimp species.

An evolutionarily conserved signaling intermediate in Toll pathways, known as ECSIT, was initially cloned as a tumor necrosis factor receptor-associated factor 6- (TRAF6-) interacting protein by yeast two-hybrid screening in mice. Through interactions with TRAF6 and MEKK1, ECSIT offers alternative means to activate NF- $\mathrm{KB}$ and $\mathrm{AP}-1$ in mammalian
TLR4 signaling (31). The interaction of DmECSIT and DmTRAF6 protein is also conserved in Drosophila, and DmEcsit efficiently activates AMP expression in S2 cells (31). However, genetic research has shown that Drosophila TRAF homologues do not participate in immune signal transduction, and the in vivo immune function of DmEcsit in Drosophila was also not reported (32). In our previous research, a shrimp ECSIT homologue was cloned from M. japonicus, named MjEcsit1. Quantitative real-time polymerase chain reaction (qRT-PCR) analysis showed detected its transcription in all test tissues and its upregulation upon Vibrio anguillarum or Staphylococcus aureus infection. Through RNA interference combined with survival and bacterial clearance assays, we showed that the shrimp ECSIT gene functioned in the anti-S. aureus immune response by regulating the expression of several AMPs (26). However, among the three identified MjTolls, the key receptor responding to bacterial infection remains unknown, as does whether and how shrimp ECSIT participates in Toll signaling transduction.

In the present study, an RNAi screen and bacterial clearance assay were used to identify the function of three Tolls in the antibacterial immunity of shrimp M. japonicas.

\section{MATERIALS AND METHODS}

\section{Immune Challenge, Sample Collection and Preparation}

M. japonicus kuruma shrimps (approximately 8-10 g each) were obtained from a local seafood market in Jinan, Shandong Province, China. They were cultured in tanks with air pumps and circulating seawater at $22{ }^{\circ} \mathrm{C}$. The shrimps were divided into experiment and control groups for an immune challenge, with 20 individuals in each group. In the experimental group, $10 \mu \mathrm{l}$ of $V$. anguillarum or $S$. aureus suspension $\left(3 \times 10^{8} \mathrm{CFU}\right)$ were injected into the last abdominal segment of each shrimp. The same volume of phosphate-buffered saline (PBS: $10 \mathrm{mM} \mathrm{Na} \mathrm{HPO}_{4}, \mathrm{KH}_{2} \mathrm{PO}_{4}$, $137 \mathrm{mM} \mathrm{NaCl}, 2.7 \mathrm{mM} \mathrm{KCl}$, and $10 \mathrm{mM} \mathrm{MgCl}_{2}, \mathrm{pH}$ 7.4) was injected into the control. At different times post-infection, shrimp hemolymph was collected with equal volumes of anticoagulant agent (450 mM NaCl, $10 \mathrm{mM} \mathrm{KCl,} 10 \mathrm{mM}$ EDTA, and $10 \mathrm{mM}$ HEPES, $\mathrm{pH} 7.45$ ) and centrifuged at $800 \times g$ for $7 \mathrm{~min}$ at $4^{\circ} \mathrm{C}$ to obtain the hemocyte pellet. Other tissues (gills, hepatopancreas, stomach, heart, and intestine) were collected simultaneously. Each sample originated from at least four shrimps. Total RNA was extracted using a Unizol reagent (Biostar Pharmaceuticals, Inc., Shanghai, China) from about $100 \mathrm{mg}$ of tissue or $3 \times 10^{7}$ cells, and the cDNA was synthesized using a FastQuant First Strand cDNA Synthesis kit (TIANGEN, Beijing, China) according to manufacturer's instructions.

\section{Recombinant Expression and Antibody Preparation}

The nucleotide fragment encoding the ECSIT domain of MjEcsitl and beta-actin gene was amplified using the primers ecsitexF/ecsitexR or actinexF/actinexR (Table 1). Fragments 
TABLE 1 | Sequences of primers in this study. Restriction enzyme cutting sites are underlined. T7 promoter sequence in primers was italicized.

\begin{tabular}{|c|c|}
\hline Primers & Primer Sequences ( 5'-3') \\
\hline \multicolumn{2}{|l|}{ Q-PCR } \\
\hline \multicolumn{2}{|l|}{ analysis } \\
\hline ecsitrtF & TIATIATGCTGCTCTTAGGC \\
\hline ecsitrtR & АТСАTСTССАТСTСТGTATCT \\
\hline alf1rtF & CAAAGTTGTTGGGTTGTGGA \\
\hline alf1rtR & CGGACTGGCTGCGTGTG \\
\hline alf3rtF & CTCTACAGCAACGGCACA \\
\hline alf3rtR & ACACCACATCCGACCCT \\
\hline alf5rtF & CTGGTCGGTITCCTGGTGGC \\
\hline alf5rtR & TTGGGTTGTGGCACTCGG \\
\hline alf6rtF & TGGTGGTGGCAGTGGCT \\
\hline alf6rtR & CGGGTCTCGGCTTCTCCT \\
\hline alf8rtF & CGCAGGCTTATGGAGGAC \\
\hline alf8rtR & GGTGACAGTGCCGAGGA \\
\hline crustin4rtF & CTCCACCACTCTCGCACTAACA \\
\hline crustin4rtR & TGATGGTCTCAGATTGGGGC \\
\hline crustin11rtF & TITCGTCTTCGTCCTGATGG \\
\hline crustin11rtR & ATTGTAGTCCTICCGCCGTC \\
\hline$\beta$-actinrtF & CAGCCTTCCTTCCTGGGTATGG \\
\hline$\beta$-actinrtR & GAGGGAGCGAGGGCAGTGATT \\
\hline toll1rtF & TGTGCCCCATCCTTCTGC \\
\hline toll1rtR & ACCACAGCCCACAAGCACA \\
\hline toll2rtF & CCATAACAGAGGACGAATTAGAT \\
\hline toll2rtR & TAGTGGAGGCAAATGCGGTA \\
\hline tol/3rtF & GAGGCACTGCGAGGGAA \\
\hline tol/3rtR & GAGACGTGGCTGAGGTATGG \\
\hline Traf6rtF & AACTAAACCAGGTCTTCAGGCTT \\
\hline Traf6rtR & CTITCCGTGCTITGATTATTCT \\
\hline \multicolumn{2}{|l|}{ RNAi } \\
\hline ecsitiF & GCGTAATACGACTCACTATAGGGGGCTGCCTICAGTGTGC \\
\hline ecsitiR & $\begin{array}{l}\text { GCGTAATACGACTCACTATAGGGATATGTAGTGATIITGAT } \\
\text { GTCG }\end{array}$ \\
\hline tol/1iF & GCGTAATACGACTCACTATAGGGCCATCCTTCTGCCACCTAA \\
\hline tol/1iR & $\begin{array}{l}\text { GCGTAATACGACTCACTATAGGGAATCTGATTTGACAAGTT } \\
\text { CCA }\end{array}$ \\
\hline tol/2iF & $\begin{array}{l}\text { GCGTAATACGACTCACTATAGGGTAAAGTCCTTGATGTGC } \\
\text { GAG }\end{array}$ \\
\hline tol/2iR & $\begin{array}{l}\text { GCGTAATACGACTCACTATAGGGTGTATAAGTTCTTGTGGG } \\
\text { TGT }\end{array}$ \\
\hline tol/3iF & $\begin{array}{l}\text { GCGTAATACGACTCACTATAGGGTGGAGCGTGGAGACAGG } \\
\text { CCC }\end{array}$ \\
\hline tol/3iR & $\begin{array}{l}\text { GCGTAATACGACTCACTATAGGGGCTGTTGACACTGTACT } \\
\text { TGT }\end{array}$ \\
\hline GFPiF & $\begin{array}{l}\text { GCGTAATACGACTCACTATAGGGTGGTCCCAATTCTCGTGG } \\
\text { AAC }\end{array}$ \\
\hline GFPiR & $\begin{array}{l}\text { GCGTAATACGACTCACTATAGGGCTTGAAGTTGACCTTGAT } \\
\text { GCC }\end{array}$ \\
\hline alf5iF & GCGTAATACGACTCACTATAGGGAGCATCGCATACGGACAT \\
\hline alf5iR & GCGTAATACGACTCACTATAGGGCTCGGTGATAAGGTITCTT \\
\hline alf6iF & GCGTAATACGACTCACTATAGGGCATGATCCTGGTGGTGGC \\
\hline alf6iR & GCGTAATACGACTCACTATAGGGTGCGGGTCTCGGCTTCT \\
\hline \multicolumn{2}{|c|}{$\begin{array}{l}\text { Recombinant } \\
\text { expression }\end{array}$} \\
\hline ecsitexF & TATC GGATCC GCAAATCCTCAACACAC \\
\hline ecsitexR & TATC CTCGAG CTAGCCACTAATAATCC \\
\hline alf5exF & TATC GGATCC ATGCGTITCCTGGTCGG \\
\hline alf5exR & TATC GGATCC TCAATCTTCCAGCCAG \\
\hline alf6exF & TATC GGATCC ATGCGAGTGTCGCTAC \\
\hline alf6exR & TATC GGATCC TTACTGATITAACCAAG \\
\hline dorsalexF & TACT CAGGAT CCGACCCTGATCTGGAGAGT \\
\hline dorsalexF & TACT CACTCG AGGTACTGGGGATCTGAGTC \\
\hline actin exF & TACT CAGGAT CCATGTGCGACGAGGAAGTT \\
\hline actin exR & TACT CACTCG AGGGAGGTGGAGGCGGCAGC \\
\hline
\end{tabular}

were then ligated into the BamHI and XhoI restriction enzyme sites of the pET-30a $(+)$ vector. The recombinant plasmid was transformed into competent Escherichia coli BL21(DE3) cells. Recombinant protein expression was induced by $0.5 \mathrm{mM}$ isopropyl thiogalactoside (IPTG) at $28^{\circ} \mathrm{C}$ for $6 \mathrm{~h}$. ECSIT domain product was insoluble and purified using His•Bind resin chromatography (Novagen, USA) after refolding by three-step dialysis. The purified protein was separated by $12.5 \%$ SDS-PAGE staining by Coomassie Blue. Protein concentration was assessed by the Bradford method (33).

For the recombinant expression of shrimp Dorsal, Alf5, and Alf6, the nucleotide fragments were amplified with primer pairs dorsalexF/ dorsalexR, alf5exF/alf5exR, and alf6exF/alf6exR, respectively (Table 1), and ligated into the EcoRI and XhoI sites of the pET$32 \mathrm{a}(+)$ vector. Protein expression was induced in E. coli Rosetta (DE3) cells by adding $0.5 \mathrm{mM}$ IPTG at $37^{\circ} \mathrm{C}$ for $5 \mathrm{~h}$. Recombinant proteins were purified by His $\bullet$ Bind resin chromatography (Novagen, USA), according to the manufacturer's instructions.

Antisera for shrimp ECSIT, Actin, and Dorsal proteins were prepared by the Qingdao Kangda Biotechnology company through using the purified recombination protein of the rECSIT domain, rACTIN, and rDorsal following the method described in a previous research (34), and then frozen at $-80^{\circ} \mathrm{C}$ for use. Antibody specificity was detected by Western blot (Supplementary Figure 1).

\section{Gene Expression Profile Analysis}

Quantitative real time PCR (qRT-PCR) was performed using an Ultra SYBR mixture protocol (with ROX, CWBio, Beijing, China) and C1000 thermal cycler (Bio-Rad, USA) to determine gene expression profiles. Gene-specific primers are listed in Table 1. The cycling conditions were: $94^{\circ} \mathrm{C}$ for $5 \mathrm{~min}$; 40 cycles of $94^{\circ} \mathrm{C}$ for $10 \mathrm{~s}, 60^{\circ} \mathrm{C}$ for $1 \mathrm{~min}$, and a melting curve from 65 to $95^{\circ} \mathrm{C}$. $\beta$-actin was used as the internal reference gene. Expression levels were normalized relative to those of the control group for each time point. The results were analyzed using the $2^{-\Delta \Delta \mathrm{Ct}}$ method and GraphPad Prism software (GraphPad, San Diego, CA, USA). Three independent experiments were performed, and data were statistically analyzed using the student's t-test and presented as the mean \pm SD. Significant differences were accepted at $p<0.05\left({ }^{*} p<0.05,{ }^{* *} p<0.01\right)$.

Western blot was performed to analyze the MjEcsitl tissue distribution and $M j$ Dorsal translocation and expression pattern after bacterial challenge. Tissues ( $25 \mathrm{mg}$ for each) collected from four individuals were polled together and homogenized in lysis buffer (50 mM Tris-HCl pH 7.5, $150 \mathrm{mM} \mathrm{NaCl}, 0.1 \%$ SDS, $3 \mathrm{mM}$ EDTA) and centrifuged at $14,000 \times \mathrm{g}$ for $15 \mathrm{~min}$ at $4{ }^{\circ} \mathrm{C}$ to collect the supernatant. The nucleoprotein and cytoplasmic protein were extracted from the shrimp gills following the manufacturer's instructions of the "Membrane, nuclear, and cytoplasmic protein extraction kit" (Sangon Biotech, Shanghai, China). After determining protein concentration by the Bradford method, 100 $\mu \mathrm{g}$ protein were resolved by $12.5 \%$ SDS-PAGE and transferred onto a nitrocellulose membrane. The membrane was blocked with 3\% skimmed milk in Tris-buffered saline for $1 \mathrm{~h}$ (TBS: $150 \mathrm{mM}$ 
$\mathrm{NaCl}, 10 \mathrm{mM}$ Tris- $\mathrm{HCl}, \mathrm{pH}$ 7.5) and incubated with a specific primary antibody (as prepared in Recombinant Expression and Antibody Preparation) at $4^{\circ} \mathrm{C}$ overnight. After washing three times by TBST (TBS, $0.02 \%$ Tween-20), the membrane was incubated with Alkaline Phosphatase Goat anti-Rabbit IgG $(\mathrm{H}+\mathrm{L})(1: 10,000$ in blocking buffer, ZSGB Bio, Beijing, China) for $4 \mathrm{~h}$. Finally, the membrane was washed by TBST, and protein bands were developed using a color-developing buffer (10 ml TBS, $45 \mu \mathrm{l}$ NBT, and $35 \mu \mathrm{BCIP})$. Western blot results were analyzed by Quantity One and GraphPad Prism software.

\section{Immunocytochemistry Assays}

Hemolymph was collected from three shrimps ( $10 \mathrm{~g}$ per shrimp) using a $5 \mathrm{ml}$ syringe preloaded with $1 \mathrm{ml}$ of anticoagulant $(0.45$ $\mathrm{M} \mathrm{NaCl}, 10 \mathrm{mM} \mathrm{KCl}, 10 \mathrm{mM}$ EDTA, and $10 \mathrm{mM}$ HEPES, $\mathrm{pH}$ 7.45) and then fixed by adding $1 \mathrm{ml} 4 \%$ paraformaldehyde. Hemocytes were collected by centrifugation at $700 \times g$ for 5 min at $4^{\circ} \mathrm{C}$, and then washed with PBS for three times, incubated in $0.2 \%$ Triton $\mathrm{X}-100$ at $37^{\circ} \mathrm{C}$ for $5 \mathrm{~min}$, washed with PBS five times, and then blocked by $2 \%$ bovine serum albumin (BSA, dissolved in PBS) at $37^{\circ} \mathrm{C}$ for $30 \mathrm{~min}$. Then, anti-Dorsal (1:200 in blocking regent) was added and samples were incubated overnight at $4^{\circ} \mathrm{C}$. After washing with PBS, the hemocytes were incubated with $2 \%$ BSA for $10 \mathrm{~min}$, then the second antibody (goat anti-rabbitAlexa Fluor 488, 1:1,000 diluted in 3\% BSA) was added, and samples were incubated for $1 \mathrm{~h}$ at $37^{\circ} \mathrm{C}$ and washed with PBS. Hemocyte nuclei were stained with 4',6-diamidino-2phenylindole dihydrochloride (DAPI, AnaSpec Inc., San Jose, CA) for $10 \mathrm{~min}$ at room temperature and washed again. The results were observed under a fluorescence microscope (Olympus BX51, Tokyo, Japan) and ImageJ was used to calculate the colocalization percentage of Dorsal with nuclei stained with DAPI.

\section{RNA Interference (RNAi)}

RNAi was performed through double-stranded RNA ( $d s$ RNA) injection to detect gene function in vivo. The partial DNA fragments of indicated genes and the control gene (GFP) were amplified using primers linked to a T7 promoter (Table 1). The PCR products were purified, enriched to $1 \mu \mathrm{g} / \mu \mathrm{l}$, and utilized as templates for $d s$ RNA synthesis. $d s$ RNA was synthesized following the instructions stated in a MEGAscript ${ }^{\mathrm{TM}} \mathrm{T} 7$ transcription kit (AM1334, Thermo Fisher Scientific).

For the RNAi assay, shrimps were divided into the control group $(d s G F P)$ and experimental group. Each juvenile shrimp (6-8 g) was injected with $d s$ RNA ( $3 \mu \mathrm{g} / \mathrm{g}$ shrimp) at the last abdominal segment. The $d s$ RNA injection was repeated after $24 \mathrm{~h}$. Shrimp gills were collected $24 \mathrm{~h}$ after the second $d s \mathrm{RNA}$ injection. Total RNA was extracted and subjected to cDNA synthesis using a commercial kit (Cat\#G492, abmGood, Canada), in accordance to manufacturer's instructions. The cDNAs were diluted 20-fold in nuclease-free water. The efficient RNAi fragment was selected after three independent experiments and used in the next experiment. The PCR primers for them are shown in Table 1, and the RNAi efficiency was detected before each further experiment.

\section{In Vivo Bacterial Clearance Assay}

Bacterial clearance assays were performed to determine whether shrimp Toll or Alf genes participated in inhibiting bacterial proliferation in vivo.

Shrimp were divided into the experimental groups (7 individuals in each group) and a control group (GFP knockdown + bacterial challenge). Bacteria $V$. anguillarum or $S$. aureus $\left(3 \times 10^{8} \mathrm{CFU}\right)$ was injected into specific gene-silenced or GFP gene-silenced shrimp. At $6 \mathrm{~h}$ after bacterial injection, 200 $\mu \mathrm{l}$ hemolymph was collected from the ventral sinuses of each shrimp. Then, $10 \mu \mathrm{l}$ hemolymph was exacted from each sample, diluted 100-fold with sterile PBS, and spread onto a 2216E plate ( $5 \%$ tryptone, $1 \%$ yeast extracted, $1.5 \%$ agar, $0.01 \% \mathrm{FeCl}_{3}$, and seawater). Four parallel operations were conducted for each shrimp. The $2216 \mathrm{E}$ plates were incubated at $37^{\circ} \mathrm{C}$ overnight, and bacterial colonies were counted the next day. The average number of colony counts of four parallel quantifications for one shrimp was utilized as the final data, which were entered into GraphPad Prism for analysis. The differences between experimental and control groups $(d s G F P)$ were analyzed by the $t$-test and shown based on $p$-values $\left({ }^{*} p<0.05,{ }^{* *} p<0.01\right)$.

\section{Bacterial Binding Assay}

Gram-negative (V. anguillarum and E. coli) and Gram-positive (S. aureus, Bacillus megaterium, Bacillus thuringiensis, and Bacillus subtilis) bacteria were selected to assess the binding activity of recombinant ALF5 and ALF6 proteins following an existing method (32). Bacteria were cultured in LB media (1\% $\mathrm{NaCl}, 1 \%$ tryptone, and $0.5 \%$ yeast extract) and collected in the mid-logarithmic phase by centrifugation at $6,000 \mathrm{rpm}$ for $5 \mathrm{~min}$. After being washed twice and resuspension in TBS (15 mM $\mathrm{NaCl}, 100 \mathrm{mM}$ Tris-HCl, $\mathrm{pH}$ 7.5), bacteria (approximately $2 \times$ $10^{6}$ cells) were incubated with $100 \mu \mathrm{l}$ of purified recombinant ALF5 or ALF6 protein $(0.8 \mathrm{mg} / \mathrm{ml})$ by shaking at room temperature for $1 \mathrm{~h}$. Subsequently, bacteria were separately washed in a TBS and 7\% SDS solution. Pellets were resuspended in $50 \mu \mathrm{l}$ TBS and analyzed by 15\% SDS-PAGE for Western blotting. A mouse anti-histidine monoclonal antibody (ZSGB Bio, Beijing, China) was utilized as the primary antibody $(1: 3,000)$, whereas alkaline phosphatase-conjugated horse antimouse IgG $(\mathrm{H}+\mathrm{L})$ (ZSGB Bio, Beijing, China) was the secondary antibody (1:10,000). Purified recombinant protein TRX was utilized as the negative control to eliminate the effect of tag protein in rMjAlf5 or rMjAlf6.

\section{Antimicrobial Activity Analysis}

Antimicrobial activities of recombinant Alfs were tested by liquid growth inhibition assays as minimum inhibitory concentration (MIC) values. Two Gram-positive bacteria (S. aureus and $B$. thuringiensis subsp. Kurstaki) and two Gram-negative bacteria (E. coli and V. anguillarum) were used in this experiment. Briefly, bacterial cells harvested at the mid-logarithmic phase were diluted to $2 \times 10^{5} \mathrm{CFU} / \mathrm{ml}$ in Poor Broth (1\% tryptone, $0.5 \%$ $\mathrm{NaCl}(\mathrm{w} / \mathrm{v}), \mathrm{pH} 7.5)$ and $90 \mu \mathrm{l} /$ well bacteria were added into a 96 well polypropylene microtiter plate. In the test, $10 \mu \mathrm{l} /$ well of serially diluted recombinant Alf protein or the control protein 
(bovine serum albumin) were added to the 96-well plate. The final concentration of peptides in the medium ranged from 3.00, $1.50,0.75,0.38,0.19$, to $0.09 \mu \mathrm{M}$. The mixtures were incubated for $48 \mathrm{~h}$ with vigorous shaking at $30^{\circ} \mathrm{C}$, and bacterial growth was evaluated by measuring the culture absorbance at $600 \mathrm{~nm}$ using a microplate reader. The minimal growth inhibition concentration (MIC) was expressed as the lowest final concentration of the protein at which no bacterial growth was observed compared with that in control. The assay was conducted in twice, with triplicate in each protein concentration.

\section{Survival Rate Assay}

The survival rate assay was performed to confirm the function of Toll3 and Alf6 in vivo. Shrimps were equally divided into three groups (30 individuals in each group), namely, one control group $(d s G F P+S$. aureus $)$ and two experimental groups $(d s$ Toll $3+S$. aureus and $d s A l f 6+S$. aureus). Each shrimp was injected with 3 $\mu \mathrm{g} / \mathrm{g} d s \mathrm{RNA}$ twice. Interference effects were detected by qRTPCR $24 \mathrm{~h}$ after $S$. aureus challenge $\left(1 \times 10^{8}\right.$ cells). The number of dead shrimps was counted every $12 \mathrm{~h}$, and the survival rates of the three groups were calculated. The cumulative survival rates and significant differences between the control and experiment groups were analyzed by GraphPad Prism and are indicated by asterisks $\left({ }^{*} p<0.05,{ }^{* *} p<0.01\right)$.

\section{RESULTS}

\section{RNAi Screening Identifies the In Vivo Function of Shrimp Tolls}

Firstly, qRT-PCR was performed to investigate shrimp Toll expression patterns during Gram-negative ( $V$. anguillarum) or Gram-positive (S. aureus) bacterial infection. The high expression of Tolls in gill tissues, together with the importance of gills tissue in shrimp breath and immunity, made us choose gills as the main organ for further study $(13,22)$. The transcription of Toll1 in the gills was noticeably upregulated by two kinds of bacterial challenge at all the tested time points, the transcription of Toll2 was upregulated only by $S$. aureus infection at a later time point in the gills, and the expression of Toll3 increased at 6-24 h post-S. aureus infection and at $24 \mathrm{~h}$ post- $V$. anguillarum infection (Figures 1A-C). These findings indicated that three Tolls may respond to bacterial infection in shrimp tissues.

To confirm the function of Toll receptors in vivo, the bacterial clearance ability of shrimp was detected before and after Toll1/2/3 knockdown. Firstly, the specificity and efficiency of Toll receptor knockdown was assured and confirmed by qRT-PCR assay (Figure 1D). Next, the $V$. anguillarum or S. aureus populations in Toll-silenced shrimp were counted and compared with those of the control group. As seen in Figure 1E, Toll1/2-silenced shrimp showed no noticeable differences in the $V$. anguillarum number compared with that of the control group ( $d s G F P$-injected shrimp) ( $p>0.05$ ), whereas a significantly higher number of $V$. anguillarum clones was seen in Toll3-silenced shrimp $(p=0.0136)$. Therefore, Toll3 may be the key Toll mediating the anti-Gram-negative bacteria response in shrimp.
By contrast, the $S$. aureus numbers in Toll1/2/3-silenced shrimp were significantly higher than those in the $d s G F P$ injected shrimp (Figure 1F). Thus, Toll1/2/3 all participated in the anti-Gram-positive bacteria immune response. Therefore, the function of Tolls during $S$. aureus infection was compared and investigated.

\section{The Expressions of Alf5 and Alf6 are Regulated by Toll 3}

In $S$. aureus-challenged shrimp, compared with the control group (dsGFP injection), Toll1 knockdown inhibited the expression of Alf4, Alf5, Alf6, and Alf8 (Figure 2A). Toll2 knockdown inhibited the expression of Alf4, Alf8, and Crustin4, but promoted the expression of Alf3 (Figure 2B). In Toll3-silenced shrimp, the expression of four AMPs was downregulated (Alf4, Alf5, Alf6, and Alf8) and AMPs were upregulated (Alf1, Crustin4, and Crustin11) (Figure 2C).

Since Toll3 also mediated clearance of Gram-negative bacterial in vivo, the gene expression patterns of shrimp under Toll3 knockdown and $V$. anguillarum infection were also detected. Notably, the expression of four AMPs (Alf3, Alf5, Alf6, and Crustin4) was inhibited (Figure 2D). The expressions of Alf 5 and Alf 6 were suppressed upon V. anguillarum or S. aureus challenge and Toll 3 silencing, indicating that they were the readout genes downstream of the Toll 3 signaling pathway.

\section{Toll3 Regulates the Expression of Alfs Through Dorsal Activation}

To clarify whether Toll3 regulates the expression of Alf5 and Alf6 through the classic transcription factor Dorsal, its activation was detected first. Cytoplasmic or nuclear proteins were prepared from the gills of normal shrimp and $1 \mathrm{~h}$ or $6 \mathrm{~h}$ after challenge with $S$. aureus. Dorsal translocation from the cytoplasm to the nucleus upon $S$. aureus infection was detected using a Dorsalspecific antibody (Supplementary Figure 1). Most of the Dorsal signal was located in the cytoplasm under normal conditions, and appeared in the nucleus at $1 \mathrm{~h}$ and kept increasing up to $6 \mathrm{~h}$ after the $S$. aureus infection, indicating its translocation from the cytoplasm into the nucleus in gills after $S$. aureus challenge (Figures 3A, 4A).Next, the cellular distribution of Dorsal was detected after RNAi of Tolls in shrimp at $6 \mathrm{~h}$ post-S. aureus challenge. Compared with the control group ( $d s G F P$-treated), Dorsal signals in the cytoplasm and nucleus of gills were not altered in Toll1- and Toll2-silenced shrimp challenged with $S$. aureus. In Toll3-silenced and $S$. aureus-challenged shrimp, the Dorsal signal was detected only in the cytoplasm of gills, and the signal in the nucleus was not detectable, indicating that nuclear translocation of Dorsal was blocked by Toll3 interference (Figure 3B). Similar results were observed in hemocytes. Most of the Dorsal signal was located in the cytoplasm under normal conditions, it appeared in the nucleus at $1 \mathrm{~h}$ and kept increasing until $6 \mathrm{~h}$ after the $S$. aureus infection, indicating that Dorsal transferred from the cytoplasm into the nucleus after $S$. aureus challenge (Figure 4A). In Toll3-silenced shrimp, the nuclear translocation of Dorsal in hemocytes was inhibited compared with that in the control group (Figures 4B-D). 
A

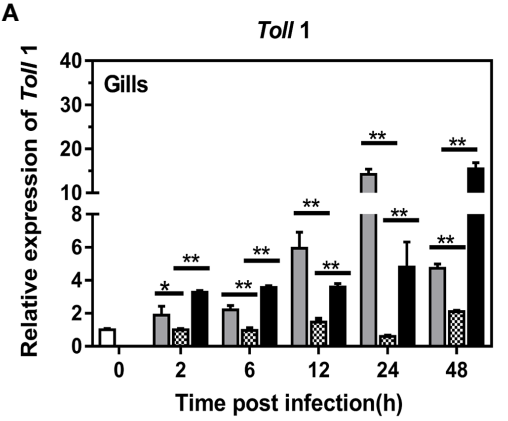

B

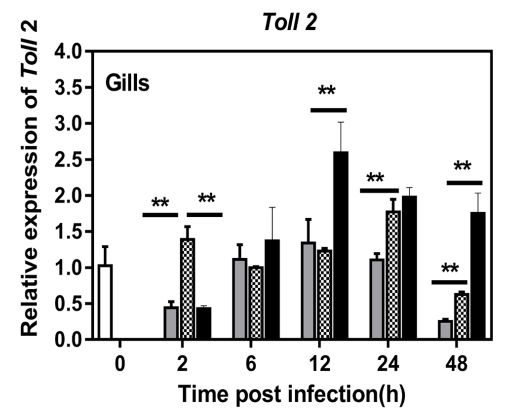

E

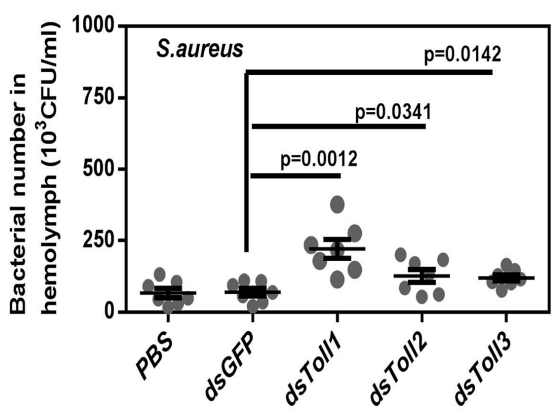

$\mathbf{F}$

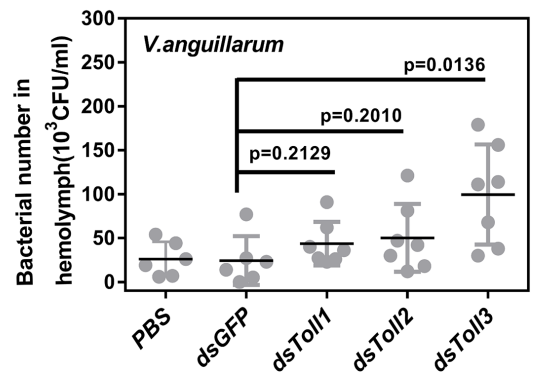

D

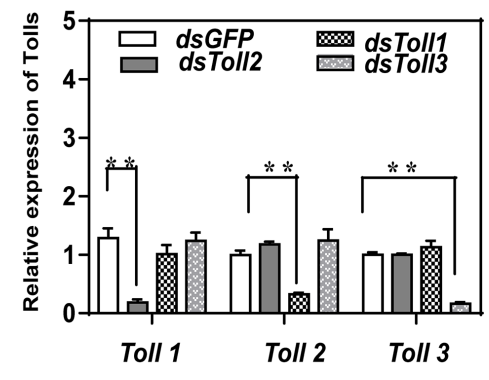

FIGURE 1 | Expression and function of Tolls in shrimp. The expression patterns of Tolls in shrimp gills upon V. anguillarum or S. aureus infection were detected by qRT-PCR. (A-C) Significant differences were analyzed between the bacteria-challenged samples and the PBS-injected samples by paired $t$-test analysis and were marked by asterisks ( $\left.{ }^{\star} p<0.05,{ }^{* \star} p<0.01\right)$. (D) The knockdown specificity and efficiency of Tolls in shrimp gills were analyzed by Q-PCR. Significant differences were analyzed by paired student's t-test analysis and are indicated by asterisks $\left({ }^{*} p<0.05,{ }^{\star \star} p<0.01\right)$. Bacterial clearance assay was performed after RNAi to detect the function of Tolls in V. anguillarum (E) or S. aureus (F) clearance. The differences between dsTolls and control groups (dsGFP and PBS) were checked by student's $t$-test and are shown by $p$-values.

To investigate whether the expression of readout genes of Toll3 was controlled by Dorsal, the Dorsal expression was interfered by $d s$ RNA injection, and the expression patterns of Alf5, Alf6, and two other genes (Crustin4 and Crustin12) was detected by qRT-PCR. Compared with the control group ( $d s G F P$ injection), the expressions of Alf5 and Alf6 were suppressed in shrimp gills under Dorsal knockdown and $S$. aureus infection (Figure 3D). Conversely, the expressions of Crustin4 and Crustin12 were not challenged under $d s G F P$ knockdown and $S$. aureus infection, and were upregulated upon Dorsal knockdown and S. aureus infection (Figure 3C). Taken together, these results suggested that in shrimp gills, $S$. aureus infection activates the
Toll3 pathway through facilitate the nucleus translocation of Dorsal and induce the expression of Alf5 and Alf6.

\section{Alf5 and Alf6 Are Efficient in Anti-S. aureus Infection in Shrimp}

To clarify whether the produced Alf5 and Alf6 are active AMPs in the antibacterial response of shrimp, their purified recombinant proteins (rAlf5 and rAlf6) were prepared and their binding activities to several bacterial strains were detected first. rAlf5 could bind to $V$. anguillarum, E. coli, S. aureus, $B$. megaterium, and B. subtilis but not to $B$. thuringiensis. rAlf6 showed the binding to all the tested bacteria, except for $B$. 
A

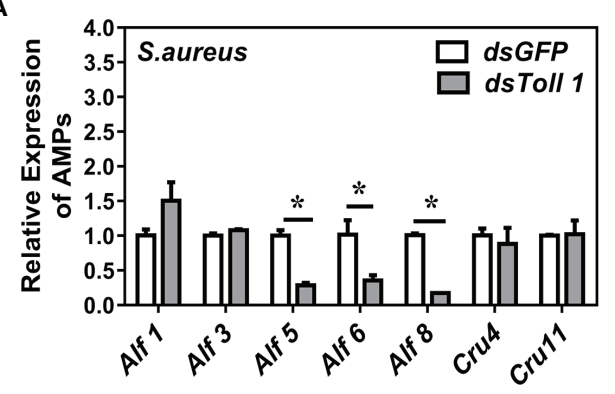

C

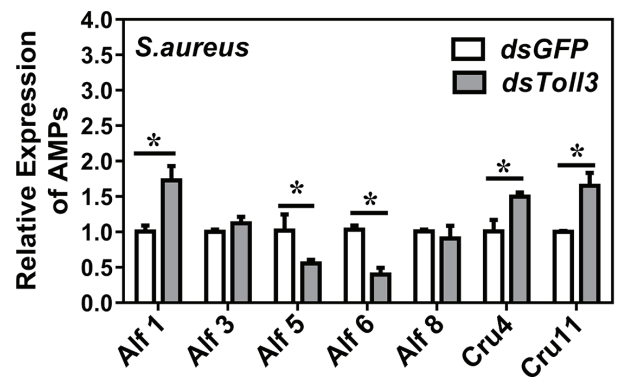

B

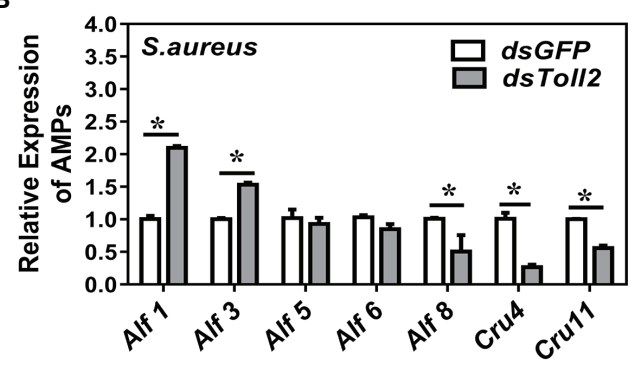

D

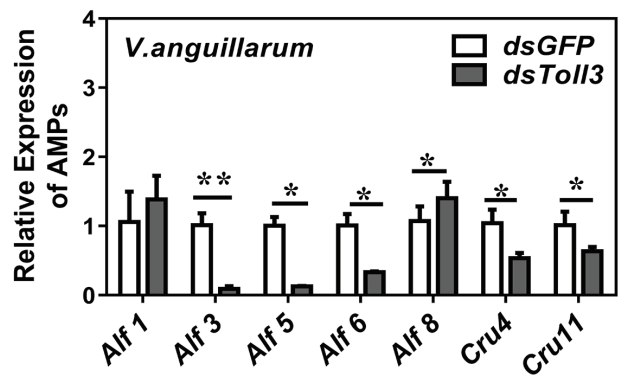

FIGURE 2 | The expression of AMP genes in shrimp under Toll knockdowns and bacterial infection. (A-C) Toll1-3 knockdowns and S. aureus infection. (D) Toll3 knockdown and $V$. anguillarum infection. Bacteria $\left(\sim 10^{8} \mathrm{CFU}\right)$ were injected $24 \mathrm{~h}$ after Toll knockdown. Total RNAs were extracted from shrimp gills $6 \mathrm{~h}$ postbacterial infection, QRT-PCR analysis was performed to test the expression of AMP genes. Three biological repeats were performed. Significant differences between the dsTolls and the dsGFP samples were analyzed by paired student's $t$-test analysis and are indicated by asterisks $\left({ }^{*} p<0.05,{ }^{* *} p<0.01\right)$.

subtilis, while the control tag protein TRX could not bind to any of the bacteria (Figure 5A). Antimicrobial activities of recombinant Alfs were tested by liquid growth inhibition assays as minimum inhibitory concentration (MIC) values, rALF5 and rALF6 showed antimicrobial activities to the tested Gram-positive bacterial strains (S. aureus and B. thuringiensis) with MIC values at $0.19 \mathrm{mM}$, but showed no antimicrobial activities to the tested Gram-negative bacteria ( $V$. anguillarum and E. coli) at the tested concentration (Figure 5B).

Next, the antibacterial activity of two Alfs was detected by an in vivo bacterial clearance assay. The shrimp were infected with $S$. aureus at $24 \mathrm{~h}$ post- $d s$ RNA injection, the bacterial number in the control group and Alf5- or Alf6-silenced shrimp hemolymph were calculated and compared. Figure 5C shows that the expressions of Alf5 and Alf6 in shrimp were suppressed at the time detected ( 24 and $48 \mathrm{~h}$ post- $d s$ RNA injection). In these conditions, a high number of $S$. aureus were found in both Alf5and Alf6-silenced shrimp compared with those in the control group (dsGFP-injected shrimp), demonstrating that Alf5 and Alf6 were active in $S$. aureus clearance in vivo (Figure 5D).

\section{ECSIT is Needed for Signal Transmission From Toll3 to Dorsal}

Firstly, the polyclonal antibody recognizing a specific singleband ( $48 \mathrm{KDa})$ ECSIT protein in shrimp tissues was prepared by using purified recombinant protein of the ECSIT domain of the shrimp ECSIT gene (MjEcist1) (Figure 6A, line 6).
The antibody could specifically recognize the purified recombinant ECSIT protein $(\sim 37 \mathrm{KDa})$ but not the control protein (recombinant ALF5 protein expressed and purified with the same system, Supplementary Figure 1A). The tissue distribution of ECSIT protein was studied by Western blot and was ubiquitously expressed in the six tested tissues, with high levels in the gill and digestive tract (Figure 6B). The expression of ECSIT in shrimp gills kept rising during Gram-negative bacteria ( $V$. anguillarum) challenge (Figure 6C) and a higher level of ECSIT expression was seen after $6 \mathrm{~h}$ of challenge with $S$. aureus bacteria (Figure 6D). These results indicated that ECSIT protein participated in the antibacterial immunity of shrimp.

Subsequently, we detected whether the expression of ECSIT protein was affected by shrimp Toll knockdown during S. aureus infection. In this research, the specific knockdown of Tolls was confirmed and shown in Figure 7A before test the expression of ECSIT. In these conditions, an obvious reduction in ECSIT protein levels was seen in Toll3-silenced shrimp but not in the Toll1- or Toll2-silenced shrimp, suggesting that ECSIT is downstream of Toll3 but not of the other two Tolls (Figure 7B). These results were consistent with ECSIT transcriptional levels in Figure 7C.

Then, we detected whether ECSIT functioned upstream of Dorsal. The cellular distribution of Dorsal and the AMP gene expression in ECSIT-silenced or control shrimp was detected $6 \mathrm{~h}$ after ECSIT gene knockdown and S. aureus infection. The nuclear translocation of Dorsal was inhibited in ECSITsilenced and S. aureus-infected shrimp (Figures 7D-e). At the 
A

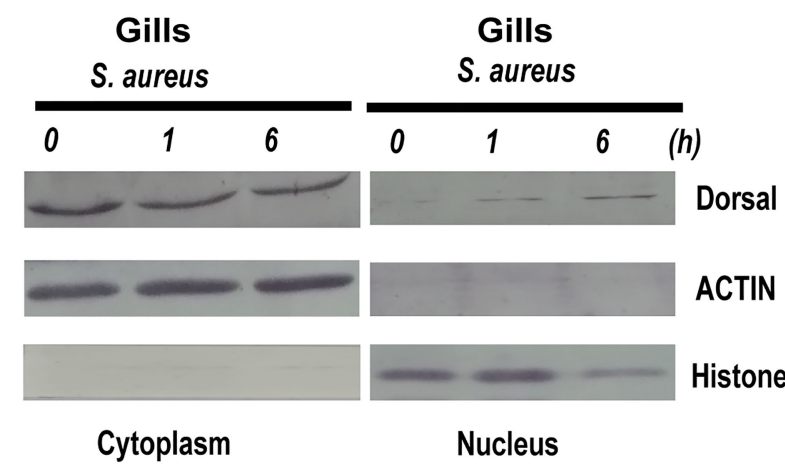

B

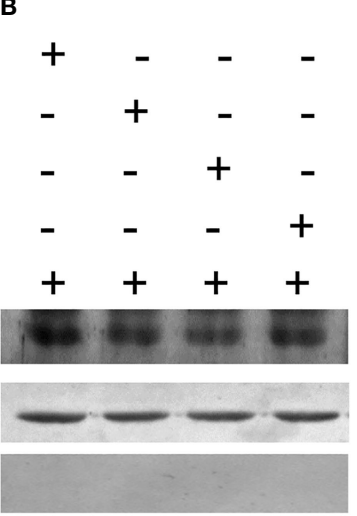

Cytoplasm

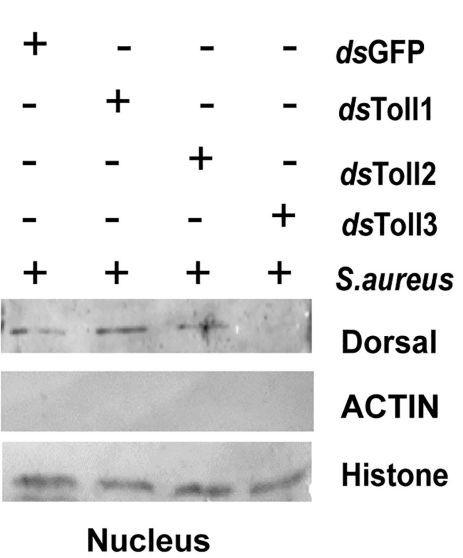

C

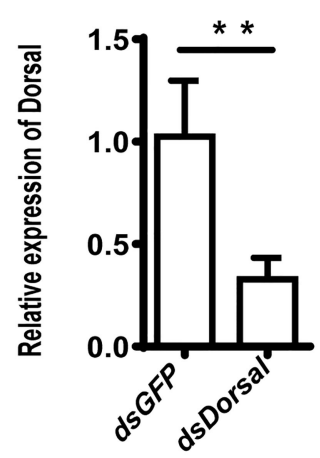

D

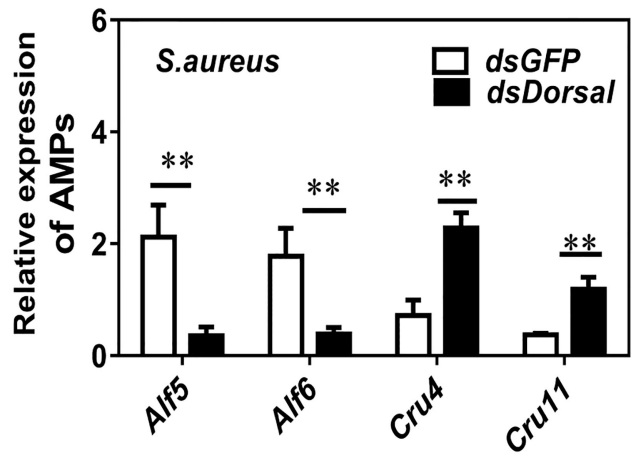

6h Post Challenge

FIGURE 3 | Toll3 regulates the expression of Alfs through Dorsal activation. (A) Western blot detection of the cellular location of Dorsal 1- and 6-h post-S. aureus infection in shrimp gills. (B) Western blot detection of the nuclear translocation of Dorsal in Toll1-, Toll2-, and Tol/3-silenced shrimp. (C) Detection of the RNAi efficiency of Dorsal by qRT-PCR. (D) qRT-PCR detection of the expression of AMPs in Dorsal-silenced shrimp and the control group. Significant differences between the $d s D o r s a l$ and the control group (dsGFP samples) were analyzed by paired student's $t$-test analysis and are indicated by asterisks $\left({ }^{\star} p<0.05\right.$, $\left.{ }^{* *} p<0.01\right)$.

same time, the upregulated expression of two readout genes (Alf5 and Alf6) was also inhibited in ECSIT-silenced and S. aureusinfected shrimp (Figure 7F) but the expression of Crustin11 was not affected, and that of Crustin4 was upregulated. These results were consistent with those in Dorsal-silenced shrimp, suggesting that they are functioned in the same signaling pathway. Taken together, these results strongly suggest that ECSIT was needed for signal transduction from Toll3 to Dorsal. A Toll3-ECSITDorsal-Alf pathway may function in anti-S. aureus immunity in shrimp.

\section{The Toll3-Ecsit1-Dorsal-Alfs Axis Opposes S. aureus Infection in Shrimp}

To further verify whether the Toll3-ECSIT-Dorsal-Alf axis was functional in in vivo anti-S. aureus shrimp immunity, a survival assay was performed. Experimental shrimps were challenged with $S$. aureus at $24 \mathrm{~h}$ post- $d s$ Toll3 or $d s A l f 6$ injection, and the shrimp survival rate was recorded every $12 \mathrm{~h}$. Figures $8 \mathrm{~A}$, B show that the expression of Toll3 and Alf6 was effectively knocked down. The survival rates of the Toll3-silenced and Alf6-silenced shrimp were significantly lower than those of the control group (Figure 8C).
These results, together with those above, suggested that the Toll3Ecsit1-Dorsal-Alfs pathway plays an important role in the antibacterial immunity of shrimp (Figure 8D).

\section{DISCUSSION}

In the present study, the in vivo function of three Tolls in $M$. japonicus was investigated and showed different roles in antiGram-positive and anti-Gram-negative bacterial immune responses in shrimp. During $S$. aureus infection, the translocation into the nucleus of the NF- $\mathrm{BB}$ homologue Dorsal was induced, and the expression of several AMPs was induced in shrimp gills. Ecsit knockdown inhibited the nuclear translocation of Dorsal and expression of Alf5 and Alf6 genes. Furthermore, the expression of ECSIT protein and downstream signaling transduction were inhibited in Toll3-silenced shrimp but not in Toll1- or Toll2-silenced shrimp. In addition, Alf5 and Alf6 were active in binding to several bacterial strains and inhibiting the proliferation of S. aureus in vivo. The knockdown Toll3 and Alfs led to remarkably decreased survival rates. Taken together, 


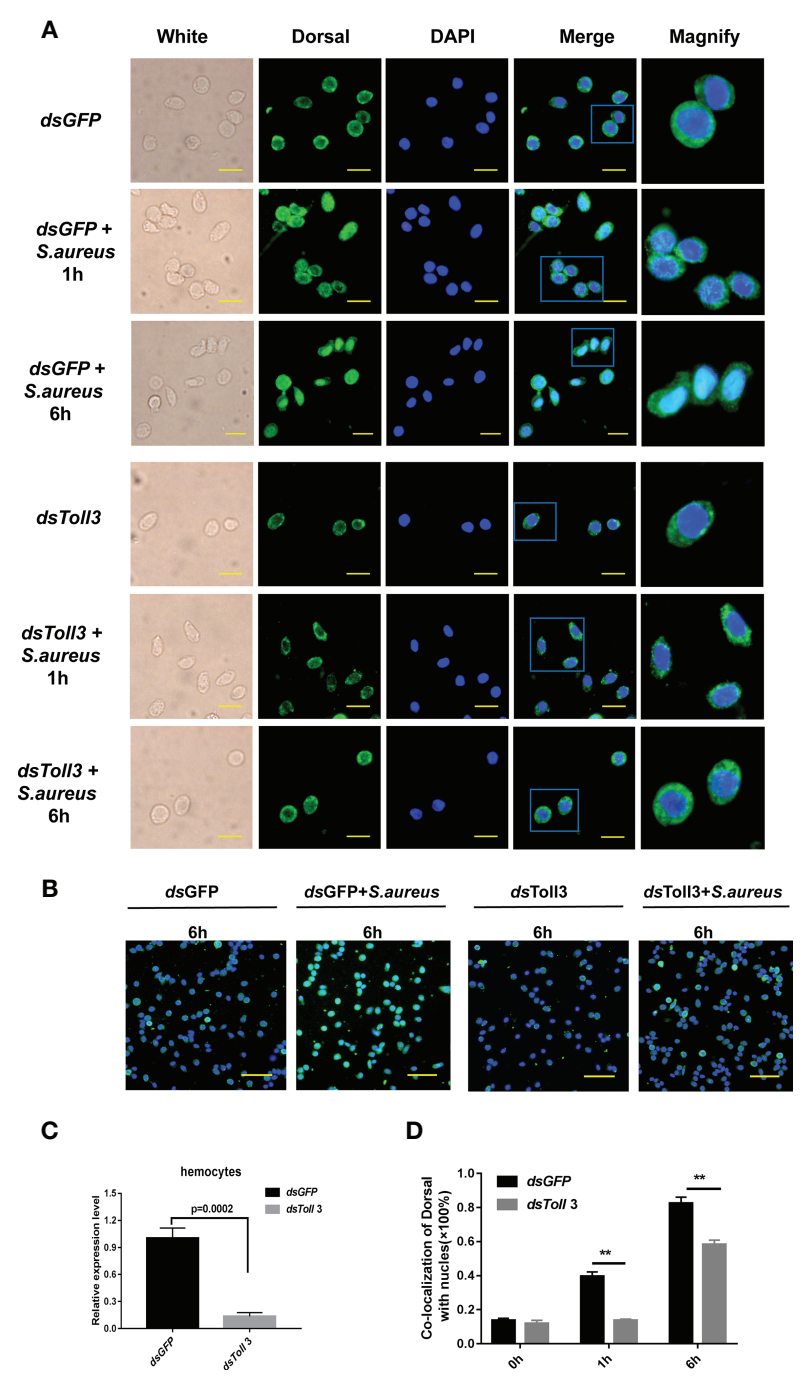

FIGURE 4 | Knockdown of To/l3 inhibits the nuclear translocation of Dorsal in shrimp. (A) Translocation of Dorsal in hemocytes of Toll3-silenced shrimp challenged with S. aureus at 1 and $6 \mathrm{~h}$ post-infection. Green fluorescence signal indicates the distribution of Dorsal in hemocytes, and blue shows the nucleus stained with DAPI. dsGFP was used as control. Bar $=20 \mu \mathrm{m}$. (B) Dorsal translocation in hemocytes of Tol/3-silenced shrimp 6h after S.aureus challenge compared with that in the dsGFP group. Green fluorescence signal indicates the distribution of Dorsal in hemocytes; blue shows the nucleus stained with DAPI. Bar = 30 $\mu$ m. (C) Efficiency of RNAi for Tol/3 in shrimp hemocytes based on RNA levels. dsGFP injection was used as a control. (D) Statistical analysis of (A) via Image J software. Significant differences between the $d s$ Tol/3 and the control group (dsGFP samples) were analyzed by paired student's t-test analysis and are indicated by asterisks ( ${ }^{\star \star} p<0.01$ ).

a Toll3-ECSIT-Dorsal-Alfs signal pathway active in kuruma shrimp under anti-S. aureus infection was disclosed. To our knowledge, this is the first report describing an antibacterial Toll signaling pathway in penaeid shrimp.

Database searching and sequence alignment analysis showed that the Toll3 in M. japonicus (MjToll3) had high sequence similarities with other crustacean Tolls (over 70\% identity). However, most of the sequences that were submitted to the database were with no functional annotation, except the $L v$ Toll 3 from L. vannamei shrimp (AEK86517.1, identity 97.2\%) and PtToll3 from Portunus trituberculatus marine crab (AKV62617.1, identity 78\%). The Toll3 proteins from those three species were ubiquitously expressed in all tested tissues and responded to the bacterial challenge. Overexpression of LvToll3 in Drosophila S2 cells showed that it was localized to the membrane and cytoplasm of cells, and its knockdown resulted in increased viral titer in vivo (35), indicating its role in recognizing viral infection, although $L v$ Toll4 was found to be more important (17). These results showed that some Tolls in shrimp may have a redundant function during infection with a given pathogen. This also applies to our findings, as knockdown each Toll led to significantly elevated $S$. aureus numbers in vivo, indicating they all functioned in anti-S. aureus infection. However, the knockdown Toll1 and Toll2 had no influence on 


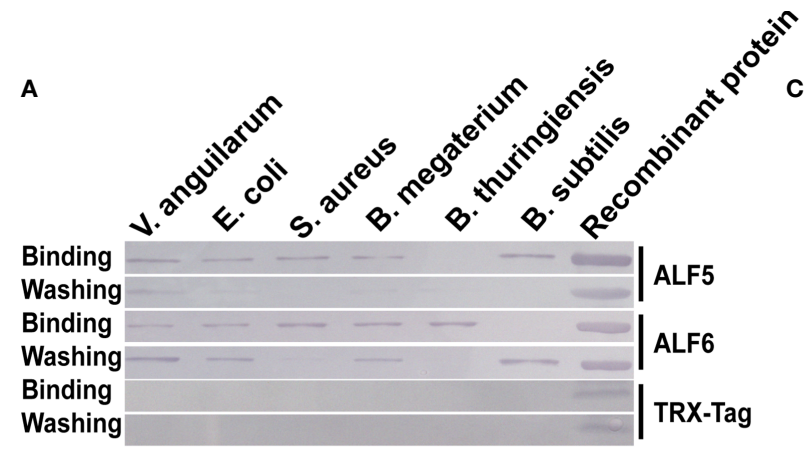

B

\begin{tabular}{lll}
\hline \multicolumn{1}{c}{ Microorganism } & $\begin{array}{c}\text { MIC }(\mu \mathrm{M}) \\
\text { Alf5 }\end{array}$ & $\begin{array}{c}\text { MIC }(\mu \mathrm{M}) \\
\text { Alf6 }\end{array}$ \\
\hline Gram-positive bacteria & & \\
Staphylococcus aureus & 0.19 & 0.19 \\
Bacillus thuringiensis subsp. Kurstaki & 0.19 & 0.19 \\
Gram-negative bacteria & & \\
Escherichia coli & 1.50 & 3.00 \\
Vibrio anguillarum & $>3.00$ & $>3.00$ \\
\hline
\end{tabular}
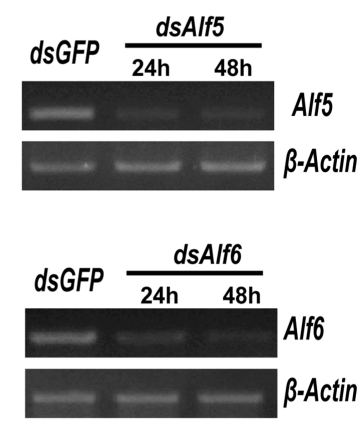

D

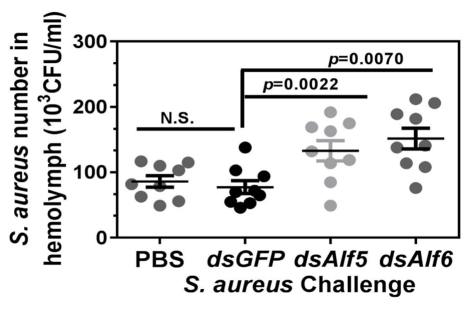

FIGURE 5 | Functional investigation of ALF5 and ALF6. (A) Bacterial binding assay of recombinant protein of ALF5 and ALF6. Various bacterial strains ( $2 \times 10^{6}$ cells) were incubated with purified recombinant protein of ALF5 and ALF6 (10 $\mu$ g) After being washed with a 7\% SDS and TBS solution, the bacterial pellets were collected and detected by Western blot with an anti-Histidine monoclonal antibody (1:4,000). The purified TRX protein was utilized as a negative control. (B) Antibacterial activity assay of rALFs. Bacterial cells $\left(90 \mu \mathrm{l} /\right.$ well) were diluted to a final concentration with $2 \times 10^{5} \mathrm{cfu} / \mathrm{ml}$ in Poor Broth, added into a $96-$ well microtiter plate. Double diluted rALF protein $(10 \mu /$ well) or the control protein (bovine serum albumin) were added to the 96 -well plate. The original final concentration was $3 \mu \mathrm{M}$. The mixtures were incubated for $48 \mathrm{~h}$ with vigorous shaking at $30^{\circ} \mathrm{C}$, and bacterial growth was evaluated by measuring the culture absorbance at $600 \mathrm{~nm}$ using a microplate reader. The minimal growth inhibition concentration (MIC) was expressed as the lowest final concentration of the protein at which no bacterial growth was observed compared with that in control. (C) Semi-quantitative RT-PCR detection of the knockdown efficiency in the Alf5- or Alf6-silenced shrimp. $\beta$-Actin was used as internal control. (D) The in vivo functional investigation of $A / f 5$ and Alf6. After the expression of $A / f 5$ and Alf6 were knocked down, bacteria $\left(3 \times 10^{8} \mathrm{CFU}\right.$ ) were injected into shrimp (seven individuals in each group), $200 \mu$ l hemolymph was collected from each shrimp at $6 \mathrm{~h}$ post-injection, and bacterial numbers in $10 \mu \mathrm{l}$ of hemolymph were counted after overnight cultivation. The PBS- and dsGFP-injected shrimps were regarded as control. Significant differences were analyzed by the student's t-test and the p value are shown. N.S. means no significant differences.

the expression of ECSIT and the downstream signaling transduction (Figure 6), indicating that another ECSITDorsal-independent pathway may exist. In P. clarkia, a Toll2ATF4-ALF1/2 pathway was found to function in anti- $V$. parahemolyticus infection (30). Whether a similar pathway is involved in the anti-bacterial immunity of $M$. japonicus shrimp needs further exploration.

Besides that, phylogenetic analysis of shrimp Toll with Tolls from Drosophila and TLR from human showed that the shrimp Toll3 clustered with Toll6 from D. melanogaster (DmToll6, with $49 \%$ sequence identity), they were then clustered with DmToll2, DmToll7, and DmTolls. The human TLRs and DmToll9 formed other independent branches (Supplementary Figure 2). In Drosophila, the Gal4/UAS system driving ubiquitous overexpression of DmToll6, DmToll7, and DmTolls caused related phenotypic changes, namely, an abdominal closure defect, extra bristles, rough eyes, vein thickening, and lethality, indicating that these four genes have more conserved molecular structures and thus may regulate similar processes in vivo.
DmToll6 and DmToll7 also function in cell migration targeting (36), embryonic development (37), neuronal networks (38-40), and olfactory development (41). It is worth noting that deletion mutant alleles of DmToll6 and DmToll7 were viable, fertile, and had no detectable defects in the septic-induced expression of antimicrobial peptide genes, suggesting that their overall innate immune response against bacteria does not have a severe defect (42, 43). These results were different from ours, since MjToll3 functioned in shrimp antibacterial immunity. Domain analysis of the shrimp and Drosophila Tolls showed that the LRR-CT domain is absent from the extracellular regions of DmToll6, and the TIR domain in the intracellular segment of most Tolls is missing from DmToll7 compared with MjToll3 (Supplementary Figure 3), which may be the reason for their lack of involvement in immune regulation. Moreover, the direct binding of Toll receptors to bacteria or PAMPs was reported in shrimp and mollusk animals $(16,44)$, showing that another activation mode for the Toll signaling pathway exists in invertebrates, perhaps another reason for their functional differences. 
A

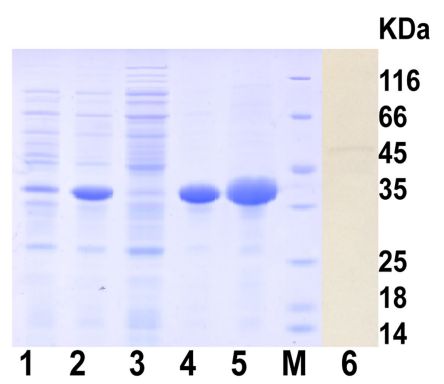

C
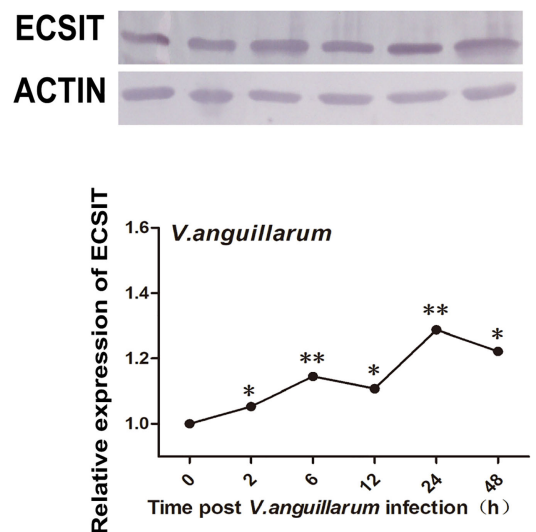

B

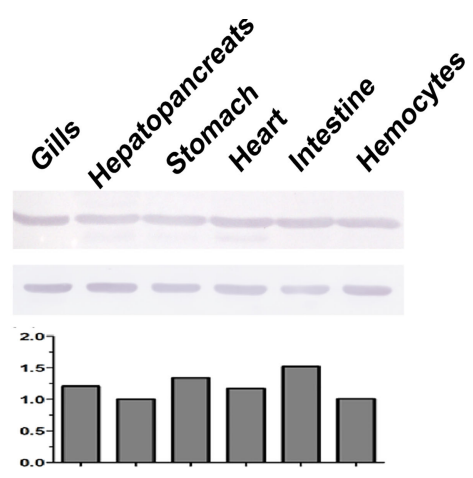

D
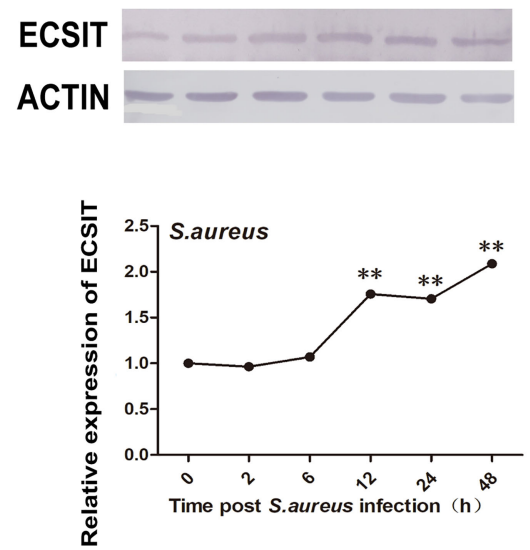

FIGURE 6 | Recombinant expression, antibody detection, and expression pattern detection of ECSIT. (A) Recombinant expression, purification, and antibody detection of ECSIT. Lane 1, total protein of recombinant BL21 (DE3) cells without induction; lane 2, total protein of recombinant BL21 (DE3) cells after induction with 0.5 mM IPTG; lane 3, soluble protein fraction from the induced recombinant BL21 (DE3) cells; lane 4, insoluble protein fraction from the induced recombinant BL21 (DE3) cells; lane 5, purified recombinant protein of ECSIT domain; lane M, standard protein marker; lanes 6 and 7, Western blot detection of ECSIT in shrimp gills and intestine using an antibody against ECSIT. (B) Tissue distribution analysis of ECSIT in normal shrimp by Western blot, and (b) quantitative analysis of Western blot result in panel (B). (C) ECSIT protein expression pattern in gills after $V$. anguillarum challenge by Western blot, and (c) quantitative analysis of panel (C). (D) ECSIT protein expression pattern in gills after $S$. aureus challenge determined using Western blot, and (d) quantitative analysis of panel (D). Significant differences were analyzed between the zero hour and other indicated time point samples by paired student's $t$-test analysis, and they are indicated by asterisks $\left({ }^{*} p<0.05,{ }^{* *} p<0.01\right)$. The experiments in (B-D) were performed three times, and similar results were obtained.

For aquatic invertebrates, the gills, together with the digestive tract, are the organs that directly face environmental pathogens. Besides that, hemocytes are considered as the direct immune response operator in animals $(16,17)$. Shrimp Tolls are widely distributed genes with high transcription in these tissues $(15,17)$. In our research, bacterial challenge led to rapid and continuous upregulation of three Toll genes in gills and intestinal tissues (Figure 1A and Supplementary Figure 4). The nuclear translocation of Dorsal in gills was suppressed only in Toll3or ECSIT-silenced shrimp but not in Toll1- or Toll2-silenced shrimp (Figure 5). However, Sun et al. observed that the induced expression of Tolls by bacterial challenge in hemocytes was transient and occurred later (12 or $24 \mathrm{~h}$ post-infection). Moreover, the nuclear translocation of Dorsal in shrimp hemocytes was suppressed not only in Toll3-silenced shrimp but also in Toll1- or Toll2-silenced shrimp (16).
Correspondingly, the AMPs regulated by Toll receptors upon bacterial challenge in hemocytes also differed from those in our research on gills. These results showed that the activation, signal transduction, and effector gene expression of the Toll pathway in those two shrimp tissues are discrepant, and the response in gills is more subtle than that in hemocytes. A similar phenomenon was also found in fruit fly. Genome sequencing showed that the expression of AMPs in Drosophila follows a complex pattern with tissue or temporal differences and is specific for each peptide. The regulatory mechanism of local (epithelial cells from the tracts that faced the microorganisms directly) or systemic induction of AMPs was different (45). For example, the expression of the Drosomysin gene was regulated not only by the Toll pathway in the fat body during the systemic response, but also by the Imd pathway in the trachea as local response (46). 
A

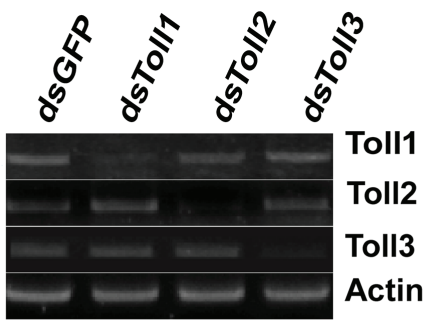

B

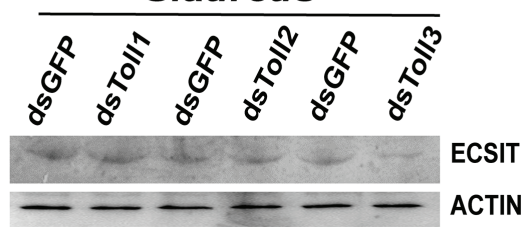

E

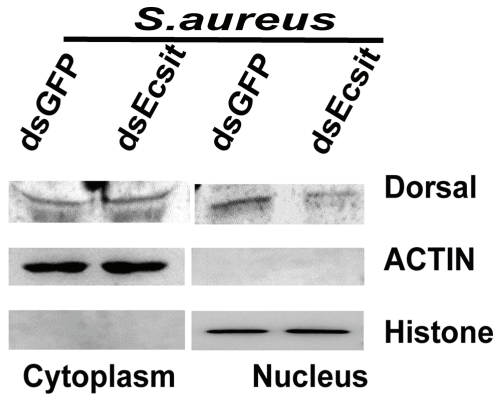

e
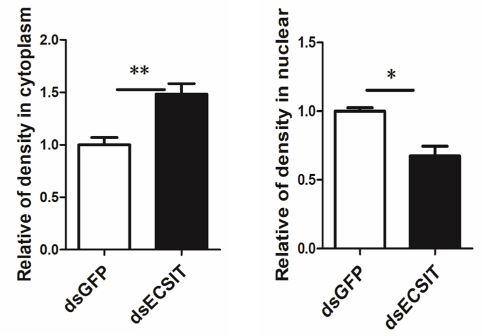

$\mathbf{F}$

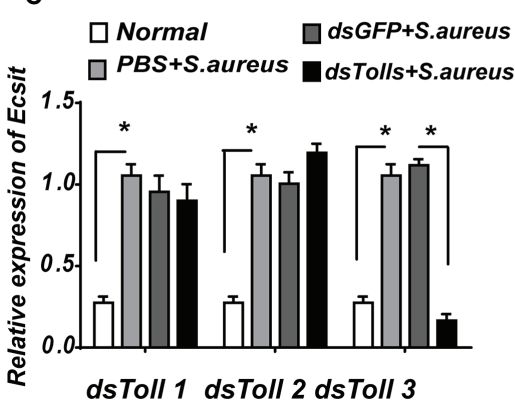

D
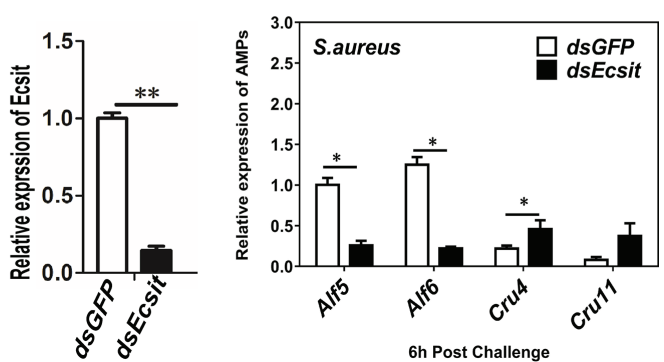

FIGURE 7 | ECSIT is needed for signal transduction from Toll3 to Dorsal. (A) Detection of the knockdown efficiency of Tolls. The expression of Toll 1/2/3 in each Toll-silenced shrimp was detected by semi-quantitative PCR. $\beta$-ACTIN was used as the internal control. (B) ECSIT protein in Toll-silenced shrimp gills was detected by Western blot. A polyclonal antibody of ECSIT was used as primary antibody (1:500 dilution). (C) The transcription of the ECSIT gene in Toll-silenced shrimp gills was detected by qRT-PCR. $\beta$-Actin was used as the internal control. (D) Detection the knockdown efficiency of the ECSIT gene. $\beta$-Actin was used as the internal control. Western blot detection the nuclear translocation of Dorsal in ECSIT-silenced shrimp. (e) Statistical analysis of the results in (E). (F) AMP expression levels in ECSIT-silenced shrimp gills at $6 \mathrm{~h}$ post-S. aureus infection were detected by qRT-PCR. All experiments were performed three times and similar results were obtained. Significant differences between samples were analyzed by paired student's t-test and indicated by asterisks $\left({ }^{*} p<0.05,{ }^{* *} p<0.01\right)$.

To date, there are only a few reports on the function of ECSIT gene in invertebrates, namely, two shrimp ECSITs from $M$. japonicus and Exopalaemon carinicauda $(26,47)$, one mollusk ECSIT from Crassostrea hongkongensis (48), one mud crab ECSIT from Scylla paramamosain, and one Drosophila ECSIT $(32,49)$. Our previous research and the data in this article showed that shrimp ECSIT was necessary for antibacterial signal transduction from $M j$ Toll 3 to Dorsal. In mammalian cells, ECSIT plays a key role in the TLR4 signaling pathway. A complex of TAK-1-ECSIT-TRAF6 was needed for the activation of NF- $\kappa B$, the interaction of TRAF6 with ECSIT, leading to the ubiquitination of ECSIT at lysine $(\mathrm{K}) 372$ residue, results in the interaction of $\mathrm{P} 50 / \mathrm{P} 65 \mathrm{NF}-\mathrm{\kappa B}$ proteins with ubiquitinated ECSIT in the nucleus, which was necessary for the production of proinflammatory cytokines and affecting gene expression in response to TLR4 stimulation $(50,51)$. Additionally, ECSIT was also located in the mitochondrial complex I, and implicated in complex stability and mitochondrial and cellular reactive oxygen species production during bacterial infection, thus contributing to the bactericidal activity of macrophages (52). In arthropods, the interaction of TRAF6 with ECSIT and their role in regulating the expression of AMPs are reported in Drosophila and mud crab $(32,49)$. However, the functional connection of ECSIT and Toll receptors is still unclear. In our research, ECSIT was proved to be needed for signal transduction from Toll3 receptor to Dorsal during $S$. aureus infection, and the ubiquitination and interaction of ECSIT with TRAF6 in M. japonicus was also discovered (data not shown). However, the ubiquitination site lysine (K) 372 residue in mammalian ECSIT is not conserved in shrimp ECSIT. Whether shrimp ECSIT functioned as the same way in mammalian system to activate Dorsal translocation into the nucleus in shrimp still needs further exploration. 

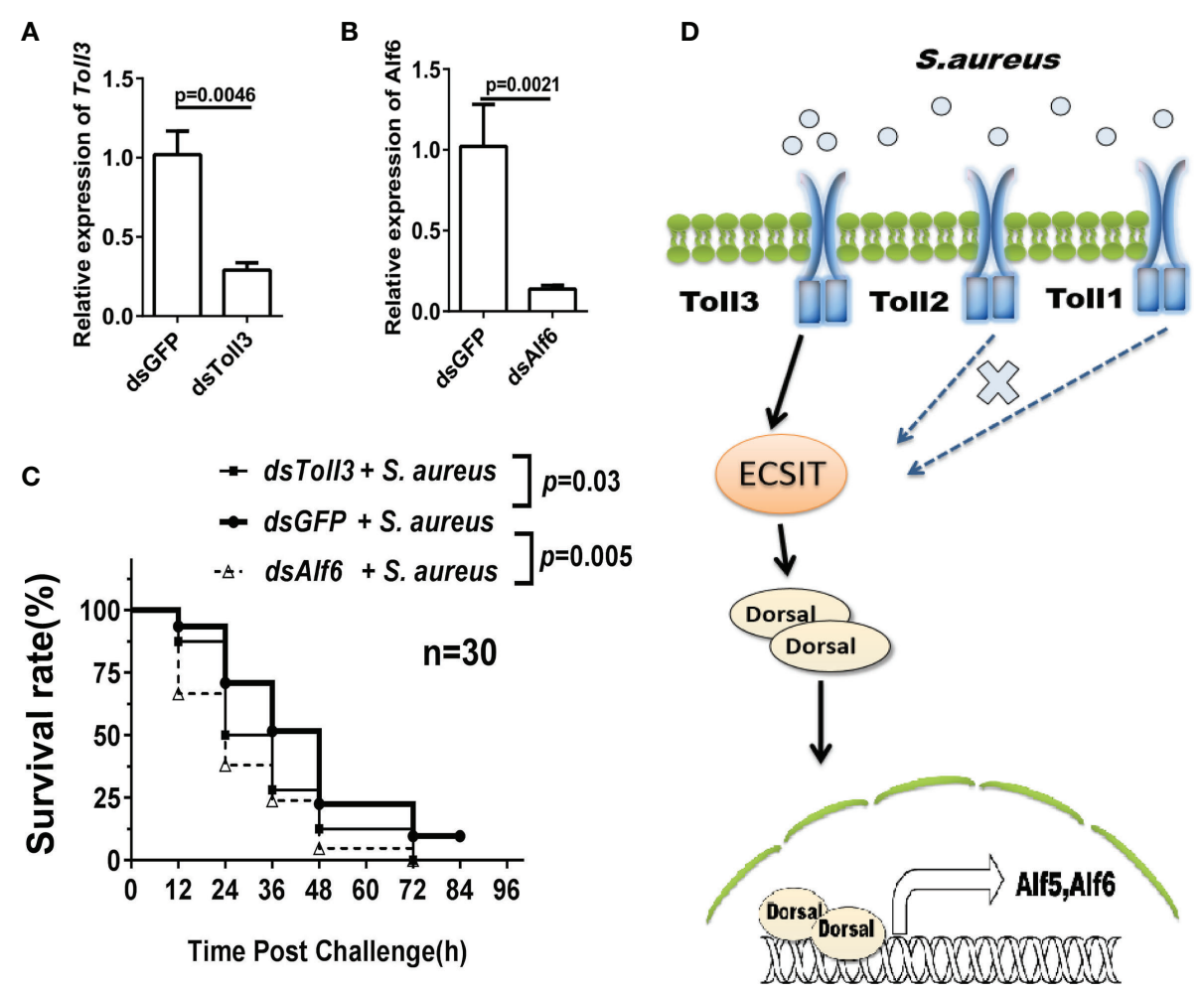

FIGURE 8 | The Toll3-ECSIT-Dorsal-Alfs axis opposes S. aureus infection in shrimp. Survival rates of Toll3-RNAi and Alf6-RNAi shrimp infected with S. aureus. (A, B) Detection of the knockdown efficiency of Toll3 and Alf6. (C) Survival rate assay. Three groups were used, with 30 individuals in each group. Each shrimp was injected twice with $3 \mu \mathrm{g} / \mathrm{g}$ dsRNA for RNAi, the second injection was administered $24 \mathrm{~h}$ after the first injection. GFP-RNAi was utilized as the control. The S. aureus $\left(3 \times 10^{8}\right.$ cells) challenge was performed after RNAi, and the number of dead shrimps was counted every $12 \mathrm{~h}$. The data was analyzed by GraphPad Prism and the $\mathrm{p}$ value are showed. (D) Model for ECSIT intermediate Toll3-Dorsal-Alf pathway against bacterial infection.

In conclusion, a novel Toll3-ECSIT-Dorsal-Alf signal pathway was identified in kuruma shrimp, and this finding enables a systematic understanding of the Toll signaling pathway in shrimp immunity. This study also provides deep insights into and enhanced comparison of the Toll/TLR signaling pathway in various species.

\section{DATA AVAILABILITY STATEMENT}

The original contributions presented in the study are included in the article/Supplementary Material. Further inquiries can be directed to the corresponding author.

\section{ETHICS STATEMENT}

All animal operations in this study were approved by the Animal Care and Welfare Committee at the Shandong University School of Life Sciences (SYDWLL-2021-99), and all efforts were made to minimize suffering.

\section{AUTHOR CONTRIBUTIONS}

Conceived and designed the experiments: C-jK. Performed the experiments: DD, X-jS, MY, LG, and QC. Analyzed the data and wrote the paper: $\mathrm{C}-\mathrm{jK}$ and $\mathrm{X}-\mathrm{jS}$. All authors contributed to the article and approved the submitted version.

\section{FUNDING}

The current study was supported by the National Key R\&D Program of China (No. 2018YFD0900303) and the National Natural Science Foundation of China (Grant Nos. 31572655 and 31272689).

\section{SUPPLEMENTARY MATERIAL}

The Supplementary Material for this article can be found online at: https://www.frontiersin.org/articles/10.3389/fimmu.2022. 807326/full\#supplementary-material 


\section{REFERENCES}

1. Akira S, Uematsu S, Takeuchi O. Pathogen Recognition and Innate Immunity. Cell (2006) 124(4):783-801. doi: 10.1016/j.cell.2006.02.015

2. Kawai T, Akira S. The Role of Pattern-Recognition Receptors in Innate Immunity: Update on Toll-Like Receptors. Nat Immunol (2010) 11(5):37384. doi: 10.1038/ni.1863

3. Akira S. Toll-Like Receptors and Innate Immunity. Adv Immunol (2001) 78:1-56. doi: 10.1016/S0065-2776(01)78001-7

4. Takeuchi O, Akira S. Pattern Recognition Receptors and Inflammation. Cell (2010) 140(6):805-20. doi: 10.1016/j.cell.2010.01.022

5. Kumagai Y, Akira S. Identification and Functions of Pattern-Recognition Receptors. J Allergy Clin Immunol (2010) 125(5):985-92. doi: 10.1016/ j.jaci.2010.01.058

6. Palsson-McDermott EM, O'Neill LA. Signal Transduction by the Lipopolysaccharide Receptor, Toll-Like Receptor-4. Immunology (2004) 113 (2):153-62. doi: 10.1111/j.1365-2567.2004.01976.x

7. Hemmi H, Takeuchi O, Kawai T, Kaisho T, Sato S, Sanjo H, et al. A Toll-Like Receptor Recognizes Bacterial DNA. Nature (2000) 408(6813):740-5. doi: $10.1038 / 35047123$

8. Hultmark D. Drosophila Immunity: Paths and Patterns. Curr Opin Immunol (2003) 15(1):12-9. doi: 10.1016/S0952-7915(02)00005-5

9. Hoffmann JA. The Immune Response of Drosophila. Nature (2003) 426 (6962):33-8. doi: 10.1038/nature02021

10. O'Neill LA, Golenbock D, Bowie AG. The History of Toll-Like Receptors Redefining Innate Immunity. Nat Rev Immunol (2013) 13(6):453-60. doi: $10.1038 / \mathrm{nri3446}$

11. Kitikiew S, Chen JC, Putra DF, Lin YC, Yeh ST, Liou CH. Fucoidan Effectively Provokes the Innate Immunity of White Shrimp Litopenaeus Vannamei and Its Resistance Against Experimental Vibrio Alginolyticus Infection. Fish Shellfish Immun (2013) 34(3):951-1. doi: 10.1016/j.fsi.2013.01.001

12. Wang PH, Yang LS, Gu ZH, Weng SP, Yu XQ, He JG. Nucleic Acid-Induced Antiviral Immunity in Shrimp. Antiviral Res (2013) 99(3):270-80. doi: 10.1016/j.antiviral.2013.05.016

13. Li FH, Xiang JH. Recent Advances in Researches on the Innate Immunity of Shrimp in China. Dev Comp Immunol (2013) 39(1-2):11-26. doi: 10.1016/ j.dci.2012.03.016

14. Perkel JM. Shrimp Study Exposes Mechanisms of Innate Immunity. J Proteome Res (2009) 8(3):1107. doi: 10.1021/pr8010777

15. Li F, Xiang J. Signaling Pathways Regulating Innate Immune Responses in Shrimp. Fish Shellfish Immunol (2013) 34(4):973-80. doi: 10.1016/ j.fsi.2012.08.023

16. Sun JJ, Xu S, He ZH, Shi XZ, Zhao XF, Wang JX. Activation of Toll Pathway Is Different Between Kuruma Shrimp and Drosophila. Front Immunol (2017) 8. doi: 10.3389/fimmu.2017.01151

17. Li HY, Yin B, Wang S, Fu QH, Xiao B, Lu K, et al. RNAi Screening Identifies a New Toll From Shrimp Litopenaeus Vannamei That Restricts WSSV Infection Through Activating Dorsal to Induce Antimicrobial Peptides. PloS Pathog (2018) 14(9):e1007109. doi: 10.1371/journal.ppat.1007109

18. Yang CJ, Zhang JQ, Li FH, Ma HM, Zhang QL, Priya TAJ, et al. A Toll Receptor From Chinese Shrimp Fenneropenaeus Chinensis Is Responsive to Vibrio Anguillarum Infection. Fish Shellfish Immun (2008) 24(5):564-74. doi: 10.1016/j.fsi.2007.12.012

19. Liu Q, Xu D, Jiang S, Huang J, Zhou F, Yang Q, et al. Toll-Receptor 9 Gene in the Black Tiger Shrimp (Penaeus Monodon) Induced the Activation of the TLR-NF-kappaB Signaling Pathway. Gene (2018) 639:27-33. doi: 10.1016/ j.gene.2017.09.060

20. Deepika A, Sreedharan K, Paria A, Makesh M, Rajendran KV. Toll-Pathway in Tiger Shrimp (Penaeus Monodon) Responds to White Spot Syndrome Virus Infection: Evidence Through Molecular Characterisation and Expression Profiles of MyD88, TRAF6 and TLR Genes. Fish Shellfish Immun (2014) 41(2):441-54. doi: 10.1016/j.fsi.2014.09.026

21. Li C, Wang S, He J. The Two NF-kappaB Pathways Regulating Bacterial and WSSV Infection of Shrimp. Front Immunol (2019) 10:1785. doi: 10.3389/ fimmu.2019.01785

22. Tassanakajon A, Somboonwiwat K, Supungul P, Tang S. Discovery of Immune Molecules and Their Crucial Functions in Shrimp Immunity. Fish Shellfish Immun (2013) 34(4):954-67. doi: 10.1016/j.fsi.2012.09.021
23. Wang D, Li F, Li S, Chi Y, Wen R, Feng N, et al. An IkappaB Homologue (FcCactus) in Chinese Shrimp Fenneropenaeus Chinensis. Dev Comp Immunol (2013) 39(4):352-62. doi: 10.1016/j.dci.2012.12.005

24. Wang PH, Wan DH, Gu ZH, Deng XX, Weng SP, Yu XQ, et al. Litopenaeus Vannamei Tumor Necrosis Factor Receptor-Associated Factor 6 (TRAF6) Responds to Vibrio Alginolyticus and White Spot Syndrome Virus (WSSV) Infection and Activates Antimicrobial Peptide Genes. Dev Comp Immunol (2011) 35(1):105-14. doi: 10.1016/j.dci.2010.08.013

25. Wen R, Li F, Sun Z, Li S, Xiang J. Shrimp MyD88 Responsive to Bacteria and White Spot Syndrome Virus. Fish Shellfish Immunol (2013) 34(2):574-81. doi: 10.1016/j.fsi.2012.11.034

26. Ding D, Chen XW, Kang LH, Jiang HS, Kang CJ. Role of Evolutionarily Conserved Signaling Intermediate in Toll Pathways (ECSIT) in the Antibacterial Immunity of Marsupenaeus Japonicas. Dev Comp Immunol (2014) 46(2):246-54. doi: 10.1016/j.dci.2014.04.016

27. Li C, Chen YX, Zhang S, Lu L, Chen YH, Chai J, et al. Identification, Characterization, and Function Analysis of the Cactus Gene From Litopenaeus Vannamei. PloS One (2012) 7(11):e49711. doi: 10.1371/journal.pone.0049711

28. Li F, Wang D, Li S, Yan H, Zhang J, Wang B, et al. A Dorsal Homolog ( $F c$ Dorsal) in the Chinese Shrimp Fenneropenaeus Chinensis Is Responsive to Both Bacteria and WSSV Challenge. Dev Comp Immunol (2010) 34(8):87483. doi: $10.1016 /$ j.dci.2010.03.008

29. Huang XD, Yin ZX, Jia XT, Liang JP, Ai HS, Yang LS, et al. Identification and Functional Study of a Shrimp Dorsal Homologue. Dev Comp Immunol (2010) 34(2):107-13. doi: 10.1016/j.dci.2009.08.009

30. Lan JF, Zhao LJ, Wei S, Wang Y, Lin L, Li XC. PcToll2 Positively Regulates the Expression of Antimicrobial Peptides by Promoting PcATF4 Translocation Into the Nucleus. Fish Shellfish Immunol (2016) 58:59-66. doi: 10.1016/j.fsi.2016.09.007

31. Kopp E, Medzhitov R, Carothers J, Xiao C, Douglas I, Janeway CA, et al. ECSIT Is an Evolutionarily Conserved Intermediate in the Toll/IL-1 Signal Transduction Pathway. Genes Dev (1999) 13(16):2059-71. doi: 10.1101/gad.13.16.2059

32. Valanne S, Wang JH, Ramet M. The Drosophila Toll Signaling Pathway. J Immunol (2011) 186(2):649-56. doi: 10.4049/jimmunol.1002302

33. Bradford MM. A Rapid and Sensitive Method for the Quantitation of Microgram Quantities of Protein Utilizing the Principle of Protein-Dye Binding. Anal Biochem (1976) 72:248-54. doi: 10.1016/0003-2697(76)90527-3

34. Du XJ, Zhao XF, Wang JX. Molecular Cloning and Characterization of a Lipopolysaccharide and Beta-1,3-Glucan Binding Protein From Fleshy Prawn (Fenneropenaeus Chinensis). Mol Immunol (2007) 44(6):1085-94. doi: 10.1016/j.molimm.2006.07.288

35. Wang PH, Liang JP, Gu ZH, Wan DH, Weng SP, Yu XQ, et al. Molecular Cloning, Characterization and Expression Analysis of Two Novel Tolls ( $L v$ Toll2 and $L v$ Toll3) and Three Putative Spatzle-Like Toll Ligands (LvSpz1-3) From Litopenaeus Vannamei. Dev Comp Immunol (2012) 36 (2):359-71. doi: 10.1016/j.dci.2011.07.007

36. Mishra-Gorur K, Li D, Ma X, Yarman Y, Xue L, Xu T. Spz/Toll-6 Signal Guides Organotropic Metastasis in Drosophila. Dis Model Mech (2019) 12 (10):dmm039727. doi: 10.1242/dmm.039727

37. Pare AC, Vichas A, Fincher CT, Mirman Z, Farrell DL, Mainieri A, et al. A Positional Toll Receptor Code Directs Convergent Extension in Drosophila. Nature (2014) 515(7528):523-7. doi: 10.1038/nature13953

38. Graham PL, Anderson WR, Brandt EA, Xiang J, Pick L. Dynamic Expression of Drosophila Segmental Cell Surface-Encoding Genes and Their Pair-Rule Regulators. Dev Biol (2019) 447(2):147-56. doi: 10.1016/j.ydbio.2019.01.015

39. McIlroy G, Foldi I, Aurikko J, Wentzell JS, Lim MA, Fenton JC, et al. Toll-6 and Toll-7 Function as Neurotrophin Receptors in the Drosophila Melanogaster CNS. Nat Neurosci (2013) 16(9):1248-56. doi: 10.1038/nn.3474

40. McLaughlin CN, Nechipurenko IV, Liu N, Broihier HT. A Toll Receptor-FoxO Pathway Represses Pavarotti/MKLP1 to Promote Microtubule Dynamics in Motoneurons. J Cell Biol (2016) 214(4):459-74. doi: 10.1083/jcb.201601014

41. Neyen C, Lemaitre B. Different Flavors of Toll Guide Olfaction. Trends Immunol (2015) 36(8):439-41. doi: 10.1016/j.it.2015.06.008

42. Yagi Y, Nishida Y, Ip YT. Functional Analysis of Toll-Related Genes in Drosophila. Dev Growth Differ (2010) 52(9):771-83. doi: 10.1111/j.1440169X.2010.01213.x

43. Tauszig S, Jouanguy E, Hoffmann JA, Imler JL. Toll-Related Receptors and the Control of Antimicrobial Peptide Expression in Drosophila. Proc Natl Acad Sci USA (2000) 97(19):10520-5. doi: 10.1073/pnas.180130797 
44. Wang W, Zhang T, Wang L, Xu J, Li M, Zhang A, et al. A New Non-Phagocytic TLR6 With Broad Recognition Ligands From Pacific Oyster Crassostrea Gigas. Dev Comp Immunol (2016) 65:182-90. doi: 10.1016/j.dci.2016.07.010

45. Imler JL, Bulet P. Antimicrobial Peptides in Drosophila: Structures, Activities and Gene Regulation. Chem Immunol Allergy (2005) 86:1-21. doi: 10.1159/ 000086648

46. Tzou P, Ohresser S, Ferrandon D, Capovilla M, Reichhart JM, Lemaitre B, et al. Tissue-Specific Inducible Expression of Antimicrobial Peptide Genes in Drosophila Surface Epithelia. Immunity (2000) 13(5):737-48. doi: 10.1016/ S1074-7613(00)00072-8

47. Ge Q, Wang J, Li J, Li J. Identification, Characterization, and Functional Analysis of Toll and ECSIT in Exopalaemon Carinicauda. Dev Comp Immunol (2021) 116:103926. doi: 10.1016/j.dci.2020.103926

48. Qu F, Xiang Z, Wang F, Zhang Y, Li J, Zhang Y, et al. Identification and Function of an Evolutionarily Conserved Signaling Intermediate in Toll Pathways (ECSIT) From Crassostrea Hongkongensis. Dev Comp Immunol (2015) 53(1):244-52. doi: 10.1016/j.dci.2015.07.015

49. Gong Y, Wei X, Sun W, Ren X, Chen J, Aweya JJ, et al. Exosomal miR-224 Contributes to Hemolymph Microbiota Homeostasis During Bacterial Infection in Crustacean. PloS Pathog (2021) 17(8):e1009837. doi: 10.1371/ journal.ppat.1009837

50. Wi SM, Moon G, Kim J, Kim ST, Shim JH, Chun E, et al. TAK1-ECSITTRAF6 Complex Plays a Key Role in the TLR4 Signal to Activate NF-KappaB. J Biol Chem (2014) 289(51):35205-14. doi: 10.1074/jbc.M114.597187
51. Mi Wi S, Park J, Shim JH, Chun E, Lee KY. Ubiquitination of ECSIT Is Crucial for the Activation of P65/P50 NF-KappaBs in Toll-Like Receptor 4 Signaling. Mol Biol Cell (2015) 26(1):151-60. doi: 10.1091/mbc.e14-08-1277

52. West AP, Brodsky IE, Rahner C, Woo DK, Erdjument-Bromage H, Tempst P, et al. TLR Signalling Augments Macrophage Bactericidal Activity Through Mitochondrial ROS. Nature (2011) 472(7344):476-80. doi: 10.1038/ nature09973

Conflict of Interest: The authors declare that the research was conducted in the absence of any commercial or financial relationships that could be construed as a potential conflict of interest.

Publisher's Note: All claims expressed in this article are solely those of the authors and do not necessarily represent those of their affiliated organizations, or those of the publisher, the editors and the reviewers. Any product that may be evaluated in this article, or claim that may be made by its manufacturer, is not guaranteed or endorsed by the publisher.

Copyright (c) 2022 Ding, Sun, Yan, Chen, Gao and Kang. This is an open-access article distributed under the terms of the Creative Commons Attribution License (CC BY). The use, distribution or reproduction in other forums is permitted, provided the original author(s) and the copyright owner(s) are credited and that the original publication in this journal is cited, in accordance with accepted academic practice. No use, distribution or reproduction is permitted which does not comply with these terms. 